\title{
Kinetics of Iron Leaching from Kaolinitic Clay, Using Phosphoric Acid
}

\author{
Román A. Hernández-Hernández ${ }^{1}$, Felipe Legorreta-García ${ }^{1}$, ${ }^{*}$, Leticia Esperanza Hernández-Cruz ${ }^{1}$, \\ Edgar A. Chavez-Urbiola ${ }^{2}$ and Eleazar Salinas-Rodríguez ${ }^{1}$ \\ 1 Laboratorio de Tecnología de Cerámicos, Universidad Autónoma del Estado de Hidalgo, \\ Área Académica de Ciencias de la Tierra y Materiales, Carretera Pachuca-Tulancingo, Km $4.5 \mathrm{~s} / \mathrm{n}$, \\ Mineral de la Reforma, Hidalgo C.P. 42184, Mexico; rahernandezh@gan.com.mx (R.A.H.-H.); \\ hcruz@uaeh.edu.mx (L.E.H.-C.); salinasr@uaeh.edu.mx (E.S.-R.) \\ 2 Consejo Nacional de Ciencia y Tecnología (CONACyT)-Universidad Autónoma del Estado de Hidalgo, \\ Área Académica de Ciencias de la Tierra y Materiales, Carretera Pachuca-Tulancingo, Km $4.5 \mathrm{~s} / \mathrm{n}$, \\ Mineral de la Reforma, Hidalgo C.P. 42184, Mexico; eachavezur@conacyt.com.mx \\ * Correspondence: profe_974@uaeh.edu.mx; Tel.: +52-771-717-2000 (ext. 2297)
}

Academic Editor: William Skinner

Received: 3 May 2016; Accepted: 15 June 2016; Published: 24 June 2016

\begin{abstract}
Kaolin is important because it has many applications in the paper, paint-coating, functional filler, extender and pigment industries. This material needs to be bleached by iron leaching to be useful for these applications because this element can be the principal cause of its undesirable coloration. In this work, the kinetics of leaching of iron contained in kaolin clays from the community of Agua Blanca Iturbide, Hidalgo, Mexico, was studied. The leaching experiments were carried out using phosphoric acid as the reagent of leaching for the iron dissolution process. Temperature, acid concentration, and particle size were investigated to determine the most important kinetics parameters during iron leaching. It was determined that the rate of iron dissolution increases with increasing of phosphoric acid concentration, the temperature, and decreased particle size of clay. Data obtained showed that iron dissolution from kaolin clay is due to the diffusion of iron through the product layer. The results revealed that the activation energy of the process was $10.18 \mathrm{~kJ} \cdot \mathrm{mol}^{-1}$.
\end{abstract}

Keywords: iron; leaching; kaolinitic clay; kinetics; phosphoric acid

\section{Introduction}

The term kaolin has a different meaning to geologists, mineralogists, and ceramists. To geologists, is a rock comprised primarily of one of the kaolin groups of clay minerals. To mineralogists, the term refers to the group for the kaolin minerals; namely kaolinite, halloysite, dickite, and nacrite. To ceramists, the term is synonymous with "china clay" meaning that it is a white ceramic raw material. Industrially, the term refers to a clay consisting of substantially pure kaolinite, or related clay minerals. They are of natural origin, or can be beneficiated to reach white or nearly white color. Its beneficiation by known methods is desirable to make it suitable for use in a white product such as paper, rubbers, paints, etc. [1,2].

Clays possess organic matter, generally lignite, as well as other colloidal minerals that confer them its characteristic colors. The red clays have ferric oxide, in minerals such as hematite, magnetite, and amorphous hydrated oxides, among others. Iron is the main contaminant in minerals of clay and kaolin. The removal of the iron from kaolin is of particular importance in the paper industry, among others, where purity requirements are high. In these minerals, iron may or may not form part the kaolinite crystalline lattice. When iron is inside the lattice, low concentrations do not affect coloration [3]. The iron oxyhydroxides are often deposited along with the kaolinite, contaminating 
and making much of the kaolin unusable for commercial applications due to the leaking of whiteness. On the other hand, other secondary minerals accompanying the clay and kaolin such as hematite, maghemite, and pyrite, iron can be removed by magnetic separation [4,5]. According to Mexican Geological Service studies, the kaolin reserves in the state of Hidalgo exceed 25 million tons; those of the neighboring states of Puebla and Veracruz are unquantified. Conduct leaching studies for bleaching kaolin in this region opens the way to applied research with the aim that in the medium term can be an impetus for the economic development of these localities currently considered to be in high poverty.

Different inorganic and organic acids or complexing reagents have been used in the dissolution of iron from these kinds of kaolin minerals. Most of these are focused on the mechanism of dissolution on hematite and magnetite, testing different acids and experimental conditions [6,7]. Different researchers have used oxalic acid for the dissolution of iron in the kaolin [6-10]. Early works, phosphoric acid was reported as leaching iron in kaolin clay [11]. Similarly, the influence of phosphoric acid in iron removal from quartz sand bleaching was also studied [12]. Also, statistical analysis was conducted to determine the most influential factors in the dissolution with organics acids used as a leaching reagent to remove iron from a kaolin mineral $[13,14]$. Recently, the general concepts and fundamentals of the biological dissolution of iron from kaolin clays had been studied by Hosseini et al. [15]. Among the organic and inorganic acids $[6-13,16]$, the biological beneficiation, $[15,17,18]$ a combination of both [19-21] and the anionic surfactants, the first are the most common reagents to remove iron oxides and oxyhydroxides contained in kaolin clay [22]. However, goethite species have been removed with anionic surfactants, increasing the whiteness index [23]. The advantages of using phosphoric acid as the leaching agent if compared with other acids are: the whiteness index that is achieved is higher, they have rapid dilution in water, and simple operation as well as ease of adding directly to the pulp. Bioleaching is an environmentally friendly method and it is also an alternative; however, bacteria are usually quite sensitive to changes in the environment in which they develop. It is crucial to consider some factors such as atmosphere, temperature, and $\mathrm{pH}$ which leads to a more complex process.

Considerable attention has been to the studies of mechanisms of dissolution, which employ synthetic minerals such as hematite, goethite, and magnetite and ignoring the complex interactions that can take place in iron dissolution from industrial minerals such as kaolin. The contribution of kinetics data for industrial-use minerals like kaolin clays it is of high importance as they are clays with complex interactions, variable iron content, and in other words very different each other due to the different geological origin they have. The kinetic data for the iron extraction from kaolin clay using phosphoric acid are very important for industrial applications such as the supply of raw material for the industry of paper and the ceramic. The aim of this work was to examine the iron leaching kinetics from kaolin clay using phosphoric acid solutions.

\section{Experimental}

For performing the experiments, Kaolin from the city of Agua Blanca Iturbide, Hidalgo State, Mexico, was used. This mineral was firstly grinded and classified by particle size. For the experimental procedure, particles of average size of $35 \mu \mathrm{m}$ were used. To characterize the mineral samples (Mineralogy and composition) X-ray diffraction (XRD) and Atomic Absorption Spectroscopy (AAS) were used.

The leaching experiments were carried out in a round bottom reactor $(500 \mathrm{~mL})$ with mechanical stirring and constant temperature. The temperature was regulated with a thermo-regulator, which is part of the equipment. In the leaching tests at $94{ }^{\circ} \mathrm{C}$, the reactor, equipped with a thermometer and a reflux condenser, was heated with a thermostatically controlled heating mantle. All leaching tests were made at atmospheric pressure for $120 \mathrm{~min}$.

Two different experiments were carried out. Firstly, the effect of the concentration $(0.1,0.5,1.0$, and $3.0 \mathrm{M})$ of the phosphoric acid at a fixed temperature of $367.15 \mathrm{~K}\left(94{ }^{\circ} \mathrm{C}\right)$ was evaluated, adding the kaolin to the solution. Secondly, the acid concentration was fixed at $3.0 \mathrm{M}$ varying the temperature in 
between 273 to $353 \mathrm{~K}$. For both experiments, the $\mathrm{pH}$ was kept constant at 1.0 adding small amounts of saturated $\mathrm{NH}_{4} \mathrm{OH}$ or $\mathrm{H}_{2} \mathrm{SO}_{4}$ solutions. Early works confirmed that optimum dissolution rate is at a $\mathrm{pH}$ value of 1, approximately [1]. The progress of extraction reaction was carried out by taking samples from solution throughout the experiments, and testing for Fe content by atomic absorption spectrometry. Variations in the mass balance due to the sampling take and the addition of reagent were taken into account for the calculations.

\section{Results and Discussion}

The results found through mineralogical and chemical analysis of the kaolin are shown in Table 1, Figures 1 and 2. The chemical composition is shown in Table 1 . The values of $\mathrm{SiO}_{2}, \mathrm{Al}_{2} \mathrm{O}_{3}$ and low contents of $\mathrm{Fe}_{3} \mathrm{O}_{4}$, indicates that this material has an ideal composition for the leaching kinetic study. Figure 1 shows the X-ray diffraction spectrum; for (a) natural kaolin mineral and (b) leached kaolin; upon a comparison of both diffractograms, it is possible to appreciate the reduction of the compound of iron oxyhydroxide (FH). A major peak corresponding to kaolinite can be appreciated, with minor signals of silica in the forms of quartz and tridymite.

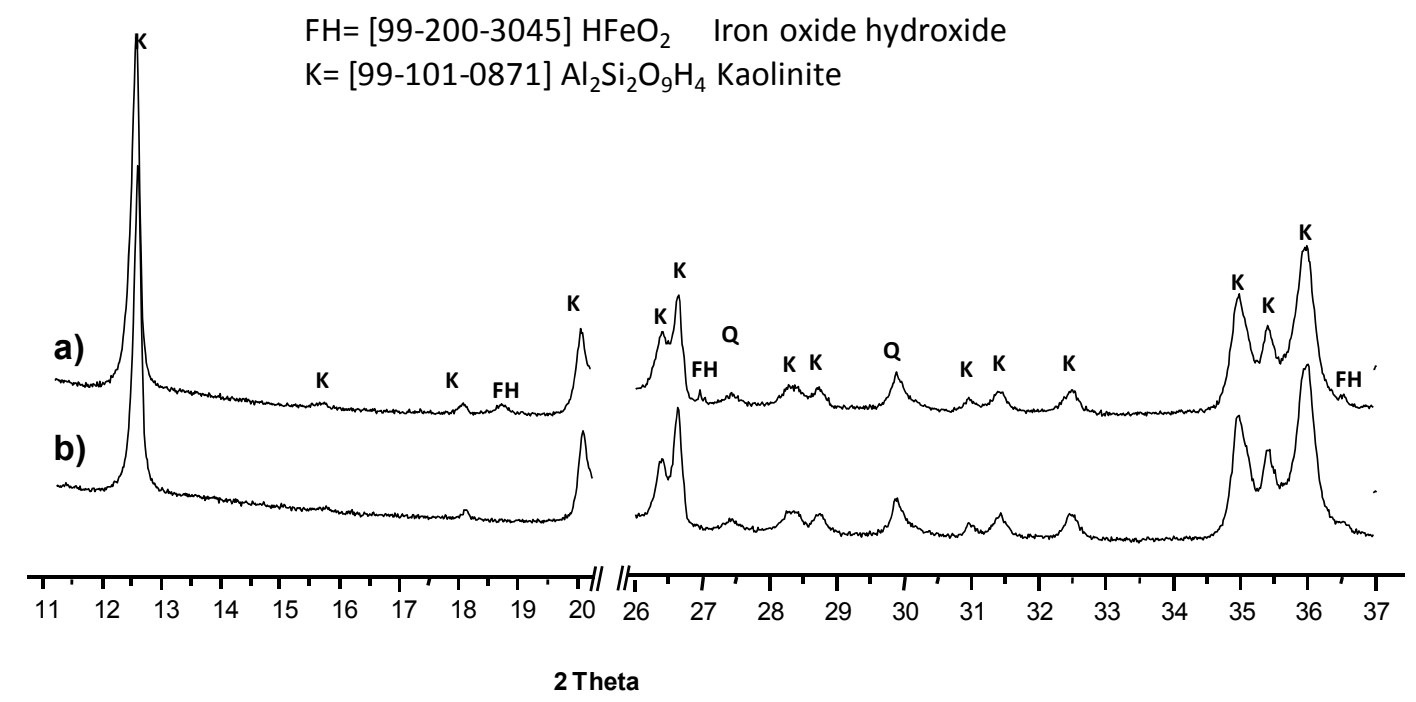

Figure 1. X-ray diffractogram of (a) kaolin mineral and (b) leached kaolin at $373 \mathrm{~K}, 3.0 \mathrm{~mol} \cdot \mathrm{L}^{-1}$ of phosphoric acid, $\mathrm{pH} 1.0$, and average particle size of $35 \mu \mathrm{m}$.

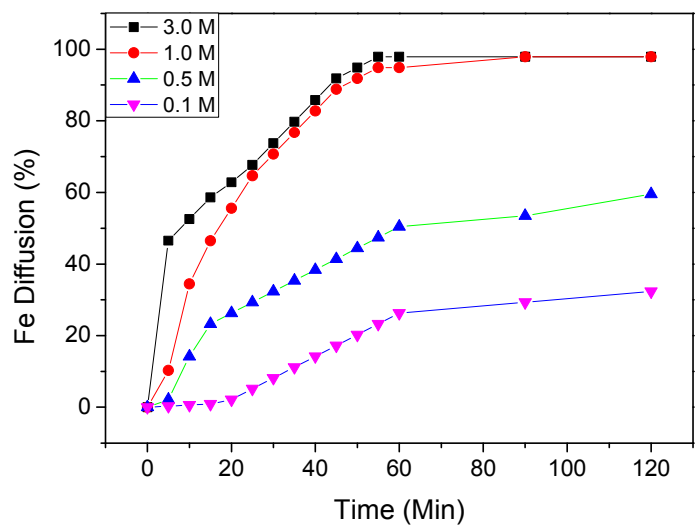

Figure 2. Effects of phosphoric acid molar concentration in Fe diffusion through time (0.10, 0.50, 1.0 and $3.0 \mathrm{M})(\mathrm{pH} 1.0,373 \mathrm{~K}, 35 \mu \mathrm{m})$. 
Table 1. Chemical Analysis of the kaolin sample.

\begin{tabular}{cc}
\hline Components & wt \% \\
\hline $\mathrm{SiO}_{2}$ & 65.00 \\
$\mathrm{Al}_{2} \mathrm{O}_{3}$ & 27.00 \\
$\mathrm{Fe}_{3} \mathrm{O}_{4}$ & 0.70 \\
$\mathrm{CaO}$ & 0.04 \\
$\mathrm{MgO}$ & 0.57 \\
$\mathrm{Na} O$ & 2.65 \\
$\mathrm{~K}_{2} \mathrm{O}$ & 2.42 \\
$\mathrm{TiO}_{2}$ & 0.67 \\
$\mathrm{LIO}^{*}$ & 0.95 \\
\hline
\end{tabular}

$\mathrm{LIO}^{*}=$ Loss of ignition.

For this work, the phosphoric acid has been used as leaching reagent due to their theoretical advantage for this use. Regarding the iron leaching, hydrogen ions play an important role in the dissolution of iron oxides with inorganic acids. The $\mathrm{H}_{3} \mathrm{PO}_{4}$ in solution provides $\mathrm{H}^{+}$, that reacts with iron oxide, and the possible reaction according Zhang et al. [12], might be:

$$
6 \mathrm{H}^{+}+\mathrm{Fe}_{2} \mathrm{O}_{3} \rightarrow 2 \mathrm{Fe}^{3+}+3 \mathrm{H}_{2} \mathrm{O}
$$

These hydrogen ions are adsorbed on the activated surface of the iron oxyhydroxide species. The hydrogen ions are adsorbed on sites of the solid surface, thus creating a surface of active centers on which the main reaction of dissolution takes place. As the hydrogen ion concentration in the solution increases, the amount of adsorbed hydrogen ions also increases, according to the adsorption theory. An increase in the number of active centers results in a corresponding increase in the dissolution rate [3].

The $\mathrm{H}_{3} \mathrm{PO}_{4}$ not only provides more $\mathrm{H}^{+}$ions $\left(\mathrm{pK}_{\mathrm{a} 1}=2.12\right)$, which will react with iron oxide; but also provides $\mathrm{PO}_{4}{ }^{3-}$ ions, which are produced while the $\mathrm{H}^{+}$is being ionized, and also have a larger complexing ability to iron ions. All these features lead to high leaching percentages of the $\mathrm{H}_{3} \mathrm{PO}_{4}$.

The possible reaction according to Zhang et al. [12], might be:

$$
8 \mathrm{H}^{+}+4 \mathrm{PO}_{4}{ }^{3-}+\mathrm{Fe}_{2} \mathrm{O}_{3} \rightarrow\left[\mathrm{Fe}\left(\mathrm{HPO}_{4}\right)_{2}\right]^{-}+\left[\mathrm{Fe}\left(\mathrm{PO}_{4}\right)_{2}\right]^{3-}+3 \mathrm{H}_{2} \mathrm{O}
$$

These multiple synergisms of the $\mathrm{H}_{3} \mathrm{PO}_{4}$, lead to the best leaching results [2].

\section{Kinetic Study}

The results obtained during kinetics study of iron extraction, are related with the effect of phosphoric acid concentration and temperature in the range 298 to $367 \mathrm{~K}$ and were treated with the shrinking core model, for heterogeneous reactions both for diffusive and chemical control.

Extraction of iron from kaolin clay can be explained with the shrinking core model [4], in which:

$$
\mathrm{aA} \text { Fluid }+\mathrm{bB}_{\text {Particle }} \rightarrow \text { Product }
$$

If diffusion controls the reaction rate through an inert product layer, the integrated rate equation is as follows:

$$
1-\frac{2}{3} X-(1-X)^{\frac{2}{3}}=K_{d} t
$$

The above equation represents the shrinking core model for diffusive control. Additionally, if the reaction is controlled by a chemical reaction, Equation (4) is transformed to Equation (5) [24].

$$
1-(1-X)^{\frac{1}{3}}=K_{c} t
$$


where $X$ is the fraction that has reacted, $t$ is the reaction time and $K_{d}$ and $K_{c}$ are the rate constants, which are calculated from Equations (4) and (5), respectively.

\section{Effect of the Acid Concentration}

In order to observe the effect of phosphoric acid concentration in the range of $0.10,0.50,1.0$ and 3.0 M, experiments were performed in the temperatures ranging of 298 to $367 \mathrm{~K}$. The results are shown in Figure 2. It shows that increasing phosphoric acid concentration increases the iron dissolution rate in the kaolin clay, especially in lower concentrations.

It was also observed that the leaching rate of iron at $1.0 \mathrm{M}$ is higher than at $0.10 \mathrm{M}$; the iron extractions were of $98.65 \%$ and $19.81 \%$, respectively.

The results found in this study are in good accordance with another study [2], where the high efficiency of iron removal was reported; but unlike our study, this work was carried out in quartz sands, using phosphoric acid.

The apparent rate constants $K_{d}$, and $K_{c}$ obtained from Equations (4) and (5), and the regression coefficients, were calculated from the graph at each concentration. The graph of Equation (4) (Figure 3a) yield straight lines with a global regression coefficient $R^{2}$ equal to 0.99 for phosphoric acid concentrations of 3.0 M. The Figure $3 \mathrm{~b}$ displays the graph of the Equation (5), it exhibits straight lines with a regression coefficient $R^{2}$ higher than 0.98 showing a slight deviation from linearity. These values of regression coefficient show that iron dissolution from kaolin clay, is controlled by diffusion through an inert product layer.

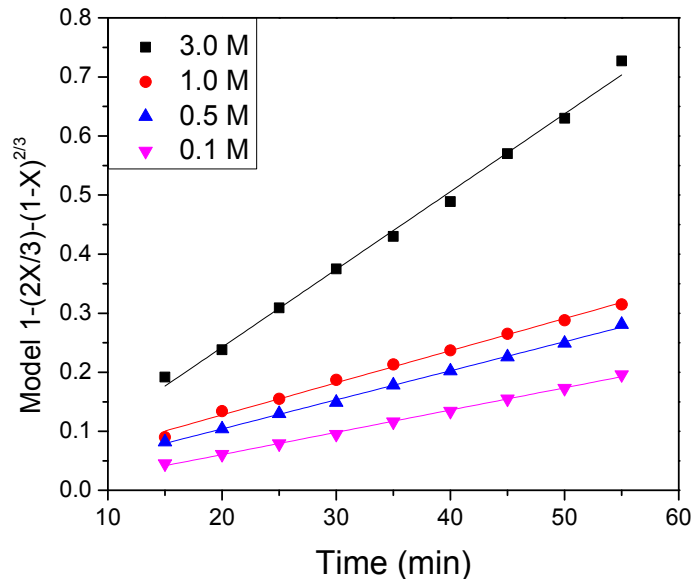

(a)

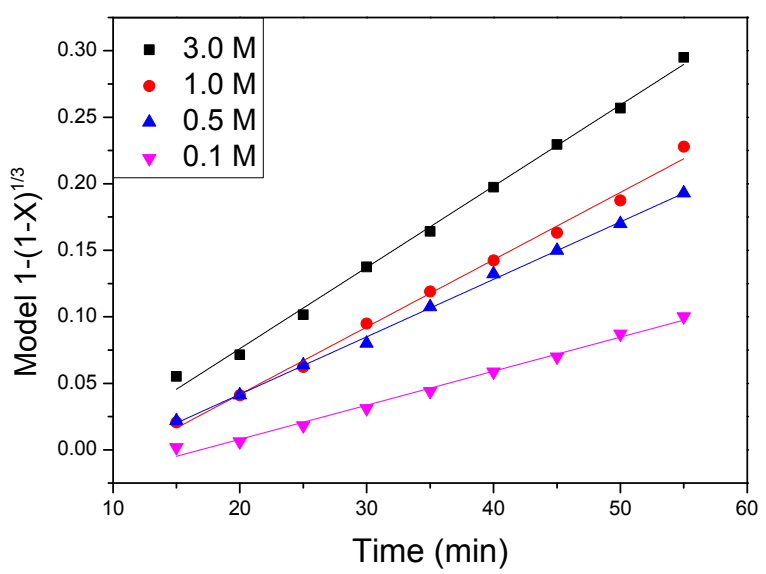

(b)

Figure 3. Graph of $1-(2 X / 3)-(1-X)^{2 / 3}(\mathbf{a})$ and $1-(1-X)^{2 / 3}(\mathbf{b})$ vs. time for the iron dissolution from kaolin clay at different concentrations of phosphoric acid $(0.10,0.50,1.0$ and $3.0 \mathrm{M})(\mathrm{pH} 1.0,373 \mathrm{~K}$, $35 \mu \mathrm{m})$.

The obtained slopes for the graph were calculated according to the model $1-(2 X / 3)-(1-X)^{2 / 3}$, from which a graph of $\log \left(K_{d}\right)$ vs. $\log \left[\mathrm{PO}_{4}{ }^{3-}\right]$ was obtained as can be seen further in Figure 4 . A straight line from this graph gave a slope from where was calculated a reaction order of $n=0.168$, according to the Equation (4) and that is shown in Figure 3. 


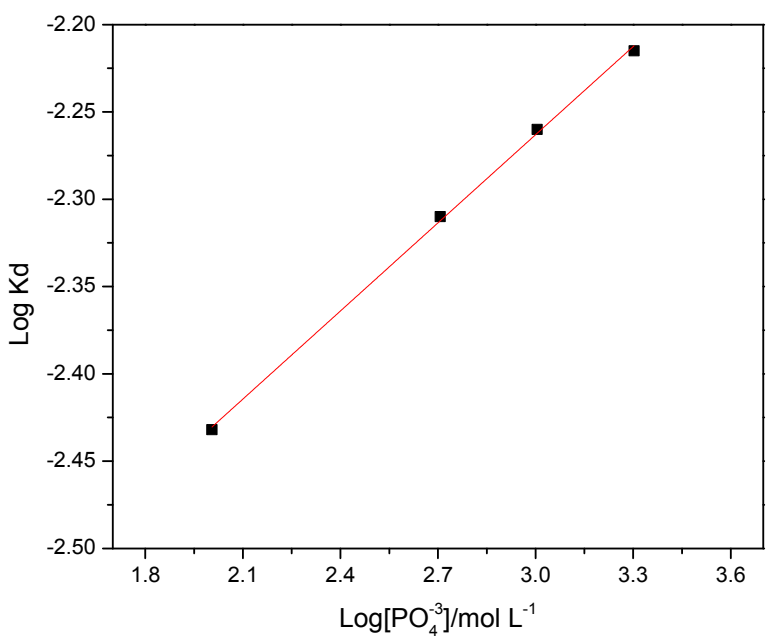

Figure 4. Graph of $\log \left(K_{d}\right)$ vs. $\log \left[\mathrm{PO}_{4}{ }^{3-}\right] / \mathrm{mol} \cdot \mathrm{L}^{-1}$ showing the order of reaction of $n=0.168$.

\section{Effect of Temperature}

With the aim of determining the effect of temperature in the kinetics of the iron extraction, several experiments in an acid solution $0.3 \mathrm{M}$ were performed, varying the temperature in the range from 298 to $373 \mathrm{~K}$. Typical rate curves with a strong temperature dependence were found. It denoted a very slow rate in the temperature range of 273 to $353 \mathrm{~K}$ exhibiting a very strong growth rate above $353 \mathrm{~K}$. This suggests that it is reasonable to use temperatures above $353 \mathrm{~K}$. That means that iron dissolution using phosphoric acid could be thermally activated to improve its efficiency. The results in Table 2 show that iron dissolution from kaolin clay in the temperature range of 298 to $373 \mathrm{~K}$, fit well with the diffusion through an inert product layer model shown in Equation (4).

Table 2. $K_{d}$ and $K_{c}$ values and regression coefficients found for each temperature for a $3.0 \mathrm{M}$ concentration of phosphoric acid is displayed with an average size of $35 \mu \mathrm{m}$.

\begin{tabular}{|c|c|c|c|c|}
\hline Temperature (K) & $K_{d} \times 10^{-3}\left(\mathrm{~s}^{-1}\right)$ & $R^{2}$ & $K_{c} \times 10^{-3}\left(\mathrm{~s}^{-1}\right)$ & $R^{2}$ \\
\hline 298 & 2.70 & 0.995 & 6.70 & 0.980 \\
\hline 313 & 3.30 & 0.999 & 7.60 & 0.992 \\
\hline 33 & 4.30 & 0.990 & 9.20 & 0.981 \\
\hline 353 & 5.40 & 0.993 & 11.80 & 0.993 \\
\hline 373 & 6.00 & 0.997 & 13.40 & 0.997 \\
\hline
\end{tabular}

The apparent rate constants, $K_{d}$ and $K_{c}$ obtained from Equations (4) and (5) and their corresponding regression coefficients were calculated from the graph at each temperature tested. These values were treated with Equation 4, and the resulting data is shown in Figure 4. The analysis of these graph revealed straight lines for $298,313,333,353$ and $373 \mathrm{~K}$ with regression coefficients $\left(R^{2}\right)$ of around 0.99 in average. It is important to mention that the results obtained from the graph of the temperature effect were also analyzed by chemical control model (Equation (5)) and the data did not fit well with this model. Therefore, it can be dismissed that the controlling stage being the chemical reaction [25].

The apparent rate constants, $K_{d}$, for iron dissolution were calculated from the slopes in the graph of Figure 5. On the other hand, a graph was made, showing the variation of $\ln K_{d}$ vs. 1000/T where $T$ is the temperature in the range of 298 to $373 \mathrm{~K}$ and from which yields the straight line shown in the Figure 6 . The regression coefficient $R^{2}$ was 0.99 . The apparent activation energy calculated from the Arrhenius plot was, $10.18 \mathrm{~kJ} \cdot \mathrm{mol}^{-1}$. This result confirmed that iron dissolution from the kaolin clay is controlled by diffusion through an inert product layer. In fact, this low energy is considered within the stated range for the controlling step of diffusion through a layer of products (below $20 \mathrm{~kJ} \cdot \mathrm{mol}^{-1}$ ) [6]. 


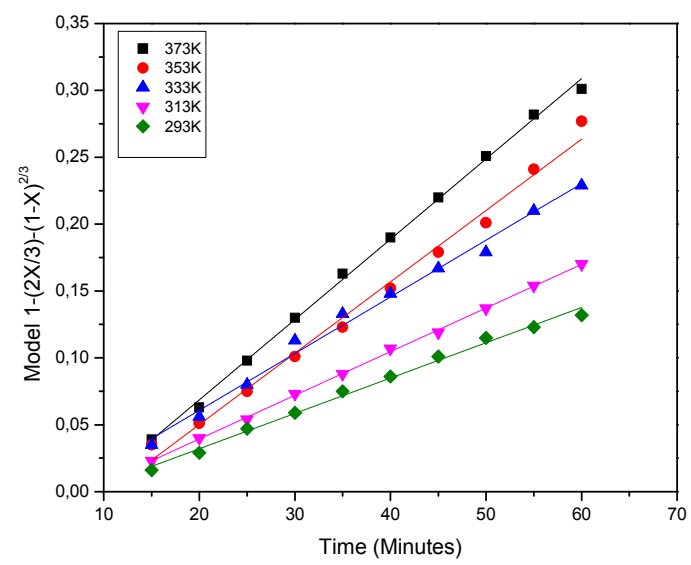

Figure 5. Graph of $1-(2 X / 3)-(1-X)^{2 / 3}$ vs. time for iron dissolution from kaolin clay at different temperatures $(298-373 \mathrm{~K})\left(3.0 \mathrm{~mol} \cdot \mathrm{L}^{-1}\right.$ of phosphoric acid, $\left.\mathrm{pH} 1.0,35 \mu \mathrm{m}\right)$.

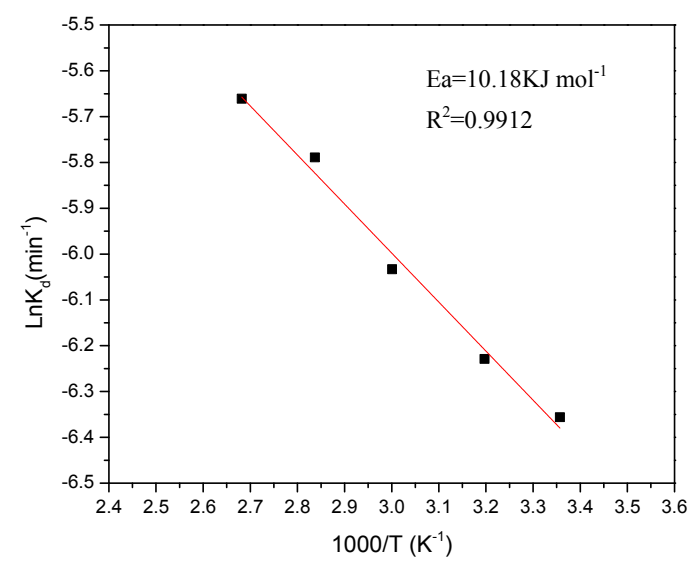

Figure 6. Graph of the iron dissolution from kaolin clay (298-373 K), 3.0 M of phosphoric acid, and $35 \mu \mathrm{m}$.

\section{Conclusions}

In this work, the kinetics of iron dissolution from kaolin clay in phosphoric acid solution was studied. The results showed that the temperature, concentration of phosphoric acid, and particle size, were of importance for the determination of the reaction kinetics. Importantly, the effect of temperature on iron dissolution is more significant at $94{ }^{\circ} \mathrm{C}$. Also, the iron dissolution increased with phosphoric acid concentration and temperature. Leaching data showed that the iron dissolution from kaolin clay occurs by diffusion through the product layer, showing an order of reaction $n=0.168$. Finally, the activation energy of the process was found to be $10.18 \mathrm{~kJ} \cdot \mathrm{mol}^{-1}$.

Acknowledgments: The authors want to thank the CONACyT FOMIX HGO of the México Government for their financial support to project 192265.

Author Contributions: Roman A. Hernández-Hernández performed the experiments as part of the doctoral thesis work, Felipe Legorreta-García performed the chemical and crystallographic analysis, Leticia E. Hernández-Cruz and Edgar A. Chavez-Urbiola wrote the paper and Eleazar Salinas-Rodríguez advised for the kinetic studies.

Conflicts of Interest: The authors declare no conflict of interest.

\section{References}

1. Patterson, S.H.; Murray, H.H.; Lefond, S.I. Industrial Minerals and Rocks; AIME: New York, NY, USA, 1983.

2. Saikia, N.J.; Bharali, D.J.; Sengupta, P.; Bordoloi, D.; Goswamee, R.L.; Saikia, P.C.; Borthakur, P.C. Characterization, beneficiation and utilization of a kaolinite clay from Assam, India. Appl. Clay Sci. 2003, 24, 93-103. [CrossRef] 
3. Norton, F.H. Fine Ceramics: Technology and Applications; Robert, E., Ed.; Krieger Publishing Co.: New York, NY, USA, 1978.

4. Guimares, S.J.F.; De Olivera, N.; De Salles, F.L. Purification of registro kaolin by magnetic separation. Trans. Inst. Min Metall. 1987, 51, 13-17.

5. Tsouris, C.; Noonan, J.; Ying, T.; Yiacoumi, S. Surfactant effects on the mechanism of particle capture in high-gradient magnetic filtration. Sep. Purif. Technol. 2006, 51, 201-209. [CrossRef]

6. Lee, S.O.; Tran, T.; Jung, B.H.; Kim, S.J.; Kim, M.J. Dissolution of iron oxide using oxalic acid. Hydrometallurgy 2007, 87, 91-99. [CrossRef]

7. Martínez-Luévanos, A.; Rodriguez-Delgado, M.G.; Uribe-Salas, A.; Carrillo-Pedroza, F.R.; Osuna-Alarcón, J.G. Leaching kinetics of iron from low grade kaolin by oxalic acid solutions. Appl. Clay Sci. 2011, 51, 473-477. [CrossRef]

8. Veglio, F.; Passariello, B.; Toro, L.; Marabini, A.M. Development of a bleaching process for a kaolin of industrial interest by oxalic, ascorbic, and sulfuric acids: Preliminary study using statistical methods of experimental design. Ind. Eng. Chem. Res. 1996, 35, 1680-1687. [CrossRef]

9. Legorreta García, F. Kinetics study of iron leaching from Kaolinitic clay using oxalic acid european. Eur. Sci. J. 2015, 11, 21-22.

10. Panias, D.; Taxiarchou, M.; Paspaliaris, I.; Kontopoulos, A. Mechanisms of dissolution of iron oxides in aqueous oxalic acid solutions. Hydrometallurgy 1996, 42, 257-265. [CrossRef]

11. Hernández, H.; García, F.L.; Hernández Cruz, L.E.; Jacuinde, A.B. Kaolin bleaching by leaching using phosphoric acid solutions. J. Mex. Chem. Soc. 2015, 59, 198-201.

12. Zhang, Z.; Li, J.; Li, X.; Huang, H.; Zhou, L.; Xiong, T. High efficiency iron removal from quartz sand using phosphoric acid. Int. J. Miner. Process. 2012, 114, 30-34. [CrossRef]

13. Legorreta García, F. Statistical treatment of bleaching kaolin by iron removal. J. Mex. Chem. Soc. 2013, 57, 261-266.

14. Veglio, F.; Pagliarini, A.; Toro, L. Factorial experiments for the development of a kaolin bleaching process. Int. J. Miner. Process. 1993, 39, 87-99. [CrossRef]

15. Hosseini, M.R.; Ahmadi, A. Biological beneficiation of kaolin: A review on iron removal. Appl. Clay Sci. 2015, 107, 238-245. [CrossRef]

16. Ambikadevi, V.R.; Lalithambika, M. Effect of organic acids on ferric iron removal from iron-stained kaolinite. Appl. Clay Sci. 2000, 16, 133-145. [CrossRef]

17. Lee, E.Y.; Cho, K.-S.; Ryu, H.W. Microbial refinement of kaolin by iron-reducing bacteria. Appl. Clay Sci. 2002, 22, 47-53. [CrossRef]

18. Guo, M.; Lin, Y.; Xu, X.; Chen, Z. Bioleaching of iron from kaolin using Fe(III)-reducing bacteria with various carbon nitrogen sources. Appl. Clay Sci. 2010, 48, 379-383. [CrossRef]

19. Toro, L.; Paponetti, B.; Vegliò, F.; Marabini, A. Removal of iron from kaolin ores using different microorganisms. The role of the organic acids and ferric iron reductase. Part. Sci. Technol. 1992, 10, 201-208. [CrossRef]

20. De Mesquita, L.M.S.; Rodrigues, T.; Gomes, S.S. Bleaching of Brazilian kaolins using organic acids and fermented medium. Miner. Eng. 1996, 9, 965-971. [CrossRef]

21. Musia, I.; Cibis, E.; Rymowicz, W. Designing a process of kaolin bleaching in an oxalic acid enriched medium by Aspergillus niger cultivated on biodiesel-derived waste composed of glycerol and fatty acids. Appl. Clay Sci. 2011, 52, 277-284. [CrossRef]

22. Legorreta-García, F.L.; Cruz, L.E.H.; Muñoz, P.F.M. Estudio de la remoción de impurezas de arcillas caoliníticas del estado de Hidalgo (México). Rev. Latinoam. Metal. Mater. 2013, 33, 313-314.

23. Aguilera, N.H.; Jackson, M.L. Iron oxide removal from soils and clays. Soil Sci. Soc. Am. J. 1953, 17, 359. [CrossRef]

24. Sohn, H.Y.; Wadsworth, M.E. Rate Processes of Extractive Metallurgy; Springer: Boston, MA, USA, 1979.

25. Levenspiel, O. Chemical reaction engineering. Ind. Eng. Chem. Res. 1999, 38, 4140-4143. [CrossRef]

(C) 2016 by the authors; licensee MDPI, Basel, Switzerland. This article is an open access article distributed under the terms and conditions of the Creative Commons Attribution (CC-BY) license (http://creativecommons.org/licenses/by/4.0/). 